\title{
Collective and Family Agriculture in Socialist Economies
}

\section{Nguyen Huu Dong}

This article ${ }^{1}$ presents an analysis of the relationship between private and collective agricultural sectors in a socialist economy with special reference to Vietnam. Any country which is going through a 'transition to socialism' or which subscribes to 'scientific socialism' shares the view of the founders of the Soviet Union that the main means of production, of which land, historically speaking, is the most important, must be collectivised. $^{2}$

\section{The Family Sector - a Universal Phenomenon}

It is also characteristic of socialist countries that the land is not completely collectivised. Even where most of the land is farmed by collective production units of various types, the peasants have the option of farming a plot of land on a private basis. The amount of land available for this varies between five and ten per cent of the cultivated land, but the option to farm a plot does not give the right either to sell it or bequeath it. In other words, farming rights do not involve property rights. Descriptive labels vary - there seems to be little distinction between 'private', 'personal', 'family' and 'complementary' plots as descriptions, except for ideological nuances. Systematic studies of the family economy are scarce (with the notable exception of Wadekin, 1973, on the 'private sector' in Soviet agriculture). Briefly, the main characteristic of the family plot is that the labour used on it is individual or household labour, and the produce obtained from it is either consumed by the producers themselves or sold by them on the market in exchange for other goods and particularly for money. While the purpose of this exchange is to increase the consumption of the producers, it cannot lead to the acquisition either of more land or of industrial means of production. Despite the insufficiency of the data available, we can nevertheless hypothesize, on the basis of the Vietnam case, that a fair amount of this cash income is hoarded.

\footnotetext{
${ }^{1}$ This paper is part of a broader study of the problems of industrialisation in Vietnam, and was written during a stay at the IDS as a Visiting Fellow. I would like to thank the IDS for facilitating my research. My thanks also to Robin Murray, Christine White, Gordon White and Olivier le Brun for their comments (and to Judith Appleton for her translation). The original longer French version appeared in Vietnam, no $1,1980$.

'I use the term 'collectivisation' advisedly, rather than terms like statisation, nationalisation or socialisation, all of which lead to other debates beyond the scope of this article.
}

The question of productivity in the private sector One of the most controversial problems in the analysis of socialist agriculture, is: which is more 'productive', the private or the collective sector? Gregor Lazarcik's figures [1974] show unequivocally that the private sector in Eastern European countries is much more productive than the collective sector, particularly in the case of animal husbandry and vegetable growing. Benedict Stavis' [1979] figures for China show that the peasants derive over 20 per cent of their income from their private plots. Official figures for Vietnam show that 65 per cent of the peasants' cash income derives from their private plots, which represent only five per cent of cultivated land. These conclusions have led a number of economists to reject collectivisation completely as a negative production factor which is used to maintain political control over the peasantry [Francisco 1979; Campbell 1974]. These arguments call for the following comments:

a) comparing production in the two sectors is a very problematic exercise. Comparisons based on cash income ignore the price system: production in the collective sector is measured in terms of the prices paid by the state for deliveries, while private sector production is measured in terms of free market prices. In the case of Vietnam, the difference between these two prices, which vary according to product and time of year, can be enormous. Prices for pork noted during a visit to Vietnam by the author will serve as an example. For one kilogram of pork, the price was 1.65 dong for obligatory sales to the state; the incentive price paid by the state for deliveries in excess of production plan was 2.5 dong; the free market price was 8 dong;

b) comparisons in terms of volume are no more convincing, as the family and collective farms grow different types of crops. Cereal production is primarily in the collective sector. Vegetables and animal products (meat, eggs, etc) are produced in both, but they are labour intensive and the labour processes involved in their production are extremely personalised. The vital factor here is the organisation of labour and labour discipline;

c) at the aggregate level, productivity in fact involves many factors other than property relations technology, capital, labour management, discipline both within and outside the production unit, etc. 
Thus, in the absence an explanation of how legal ownership as such plays an active role in determining the productivity of labour, we are forced to conclude that the case against collective agriculture put forward by the authors quoted above is an idea that is an old as anti-communism - that peasants, like capitalists, are unable to work productively except on the basis of individual incentives.

Is collectivisation necessary? We have already established the existence of a broad consensus on the necessity of collectivisation in socialist countries. First there is the point, made with considerable force by Dodd [1966], that this guarantees that agricultural surplus in the countryside is gathered by the state. In addition, collectivisation of land is a pre-condition for a thoroughgoing system of water control, a very problematic area in a country like Vietnam. Collectivisation not only reduces the land wastage involved in maintaining boundaries between privatelyowned pieces of land (these accounted for fully three per cent of cultivable land in the Red River delta), but also makes way for a new division of labour along with mechanisation and agricultural innovation, none of which is viable on sub-divided private land.

In analyses by economists in socialist countries, especially in the 1950s and 1960s, collective production was frequently regarded as a guarantee of the continuing socialist character of the country. The various forms these units take (kolkhoz, sovkhoz, lowlevel cooperative, high-level cooperative, people's commune ...) are considered equivalent to comparable degrees of socialisation. During the last decade, however, this question has been subject to some scrutiny. In the USSR, the sovkhoz is not very different from the kolkhoz, and in China, the people's communes are no longer presented as the model for an elusive socialism.

It may be that a point is reached when one is forced to recognise that complete collectivisation is neither possible nor necessarily socialist (note, however, that this view is still contested by some orthodox Marxists). One is then able to reconsider the problem of the private or family sector in terms of the rural reproduction process. Put bluntly, the question is: why is there such a large private sector (in terms of individual cash income) in socialist economies and what is its relationship to the collective sector?

\section{Survivals, Complementarity, Transfer: Some Theories}

Without attempting an exhaustive analysis, we can say that economists in socialist countries (and others) have two broad explanations for the existence of the private plot.
The first is basically that private plots are one of the concessions made by the state to the peasantry [Dunman 1975] when land is collectivised. In other words, the assumption is that when conditions are ripe technically (modernisation), economically (sufficient goods distributed by the state sector), and ideologically (peasant collective consciousness) these plots will be phased out in favour of completely collectivised agriculture. The second explanation [Nguyen Xuan Lai 1967] stresses complementarity of the relationship between family and collective economies. They occupy two different positions within agricultural production and thus constitute two different sources of peasant income: cooperative labour provides their staple food needs (cereals), and 'family labour' produces other foods (vegetables, eggs, meat, poultry) as well as most of their cash income. We must add the manufactured goods which the peasants obtain through the cooperative. In other words, the two sectors are linked, and there is thus a need to avoid both 'leftist' attempts to eliminate the family economy, and 'rightist' policies which favour the family economy to the detriment of the collective economy. The recommended balance should fuse individual and collective interests.

These two theories (which are not necessarily antagonistic) prompt the following comments. First, implicit in the first theory of progress towards the necessary disappearance of the private plot with the advance of socialism is the idea that it is "peasant nature' to cling to the principle of private property and to be motivated by more or less self-centred considerations. Second, saying that the two types of economy are complementary is to do no more than recognise the real situation; it is in no way an analysis of the relationship between the two economies. The same lack of analysis would be evident in a characterisation of the relationship between the sexes as complementary. Moreover, this analysis gives no clue to the social relations which allow these two economies to be reproduced.

The Vietnamese case has recently been taken up in an original and provocative manner by Alec Gordon [1978]. He focuses on the importance of the private plot for peasant incomes in Vietnam, and makes some new points, which are summarised below:

a) the plots worked by private labour in fact exceed the theoretical five per cent of cultivated land; an additional approximately seventeen per cent of the land has been illegally occupied. This quasiprivatisation was made possible, according to Gordon, by the disorganisation in the cooperatives in the wake of the intensification of the war in the mid1960s. Moreover, Gordon sees no reason to exclude the possibility of a 'spontaneous' development of a 
new stratum of rich peasants, who acquired land through their contacts and through deals made with members of the state apparatus;

b) more private plots meant less collective land and labour. Gordon calls this a 'zero sum game', on the assumption that time spent on a private plot is time lost to the cooperative;

c) Gordon's last, and most sophisticated, argument is that an actual transfer of resources from the collective land to the private plot takes place, made possible by the difference between the value of the labour force on the one hand and the price of the products of this labour on the free market on the other. In as far as the cooperatives guarantee the peasants a sufficient quantity of their basic food needs ( $320 \mathrm{~kg}$ per year) at low prices, they provide the basis for them to reproduce themselves at low cost. Since this is the same labour force that works on the private plots, the products of the latter are similarly low cost, which when sold on the free market give considerable profit. If this profit remains in the private sector, it may provide the basis for the de facto re-privatisation of land suggested above.

Some comment is needed on this. First, the 'zero sum game' is simply another way of saying that the peasants prefer to indulge in private rather than collective labour - in other words, the same old idea of the individualistic character of the peasantry. Gordon also suggests that complete collectivisation would be a mark of socialist development. Neither of these assertions, whether implicit or explicit, takes us any further in our analysis.

Second, although the idea presented of a transfer of resources by means of a system of differential values is attractive, it is too confused. It is in fact very easy to confuse the value of labour power, the price of labour power, the value of products, production costs and the sale price of these products. To take one example, it is not possible to calculate an abstract value of labour power. It is quite false to conclude that the value of labour power is low because sufficient supplies of paddy (the staple food) are provided by the cooperatives at low cost. This is to consider the reproduction of the labour force purely from nutritional or biological points of view both of which are simplistic.

Nevertheless, the discussion of the value of the labour force opens up interesting horizons. One is thereby led to consider the concept of value, which according to Marx is not a quantity of labour time but is above all a specific form of control of labour and surplus labour (Marx uses the term 'value form'). One is thus confronted with the question of the nature of the system of social relations within which peasants work, the system through which this labour takes on a specific form.

This question will now be examined under the general theme of the control of labour and surplus labour in Vietnamese agriculture. We must first note that the controls are social rather than administrative or police controls (although the latter have existed, or may still exist as incidental controls). Social controls derive from the logic of how the social system itself functions, a logic which may be either encouraged or thwarted by state policy.

\section{Control of Labour and Surplus Labour: the Role of the Family (Private) Plot}

The key questions are:

- what is the function of the private plot in the agricultural context?

- what are the means of control of labour and of surplus labour in socialist agriculture?

The answer to these questions will throw new light on the private plot: this land is neither the expression of emerging capitalism, nor does it represent a concession to 'egoistical peasant nature'. In order to establish this point, we shall make a number of comments on the Vietnamese experience of land reform and the transition to socialism in the aftermath of the war of national liberation against French colonialism.

Private property and the labour process The desire of impoverished Vietnamese peasants of the Red River delta, after centuries of chronic famine, to own land as a guarantee of their own utilisation of the products thereof is neither a sign of capitalist tendencies, nor proof of 'peasant individualism'. Seen in context, it is part of the struggle against the social regulation imposed by famine, and against feudal exploitation. Property in this historical context was a form of distribution: land ownership was equated with guaranteed disposition of part of the harvest (before the moneylenders arrived on the scene).

Marx's explanation of the creation of surplus value and exploitation is modelled on 'traditional' peasant society: surplus value is the product of surplus labour (as opposed to necessary labour) and is appropriated by the owners of capital. Landlords appropriate part of the harvest as rent, this rent being the other side of the land ownership coin. Landlords were not interested in the agricultural labour process as such. Vietnam's colonial experience is a good example of how landlords' wealth increased the more divided their land was, ie, the more peasants were paying rent as tenants. The important point for the landlord was to control the harvest, or more precisely, to control the 
final product of the labour process. It is in this context that we contend that the control of surplus labour is effectively the same as controlling the agricultural surplus.

However, Marx tells us that distribution is a mirror image of relations of production. What are the dominant relations of production where the peasant is landowner and producer? We are provisionally tempted to say that these are family relations of production. Legal ownership of property is not a mere ideological illusion but embodies relationships which are extremely important for social reproduction, such as inheritance, extended families, clans, marriage, etc. Inheritance is both the framework in which land ownership is transferred directly, as well as being a powerful means of controlling the labour of children and young people in the family unit. This implies a double control when we add in the agricultural labour process itself, which is based on the transmission of empirical knowledge. Arranged marriages and dowries are means of enforcing the system, and possibly extending land ownership. Polygamy in precolonial and colonial Vietnam was an example of how the landlord might not only extend his property, but in addition might also use his wives as very efficient managers of his land. The range of women's labour was fairly familiar - work in the fields, domestic work, and 'trading', in addition to bringing up their children.

Family stability and family relationships all derive from a form of 'private property'. This being true, it is easy to see why capitalist relations of production, most pronounced in the case of landlessness (separation of the producer from the means of production), also imply the breakdown of the traditional family structure and destabilisation of the family unit itself.

\section{Collective Ownership, Mechanisation, and the Control of Surplus Labour}

Let us now return to the idea of ownership in the sense of complete control by the producer of the labour process on the land. The Vietnam Communist Party stressed that after having solved the problem of distribution by land reform (which was carried out between 1953 and 1956 and led to a considerable increase in peasant consumption), the labour process itself must be transformed. The establishment of cooperatives was supposed to introduce a new division of labour, characterised by work specialisation and mechanisation, a process implying reorganisation of the whole of the rural labour force.

The question which now arises concerns the nature of cooperative land ownership, especially as this form of ownership is not a legal form, since the land belongs to the state. Cooperative ownership is first of all a form of distribution to the peasant producers which takes place through a system of work points. On the one hand the peasants are allotted part of the cooperative's products in kind, and rarely their cash equivalent, and on the other they have access to manufactured goods supplied by the state and sold at subsidised prices. The cooperative also pays for all social expenses for health, education and entertainment. Many cooperatives have set up funds for scholarships to enable young people to pursue their studies in town and return to work in the village. The cooperative also takes responsibility for transferring income to the state since it handles all taxes. The equivalent of ten per cent of the volume of all production in the cooperative is now collected as a compulsory levy according to the most recent decisions. The remaining 90 per cent is a theoretical sum, as calculations are done on the basis of planned rather than actual production. Cooperatives may thus use any production in excess of the plan for their own funds for collective consumption (but not for investment or amortisation, all of which the state takes care of).

We have shown that the cooperatives' role in transferring income to the state has had a privileged position for some time in discussions about the necessity of collectivisation. But in a society as threadbare as Vietnam has been during periods of war, the role of the cooperative in guaranteeing the bare necessities of life is fundamental. It is understandable that the 'welfare cooperative' aspect be stressed in this context. But this should not obscure the fact that it is only peasant surplus labour that makes a new division of labour possible, and that neither service activities nor industrialisation are on the cards before the food problem has been resolved.

The question is one of knowing exactly what form the control of surplus labour takes in a cooperative. As private property disappears, there is a parallel reduction of 'traditional' control over surplus labour. However, while formal property relations may change suddenly, as the result of legislation, the change in control is a gradual social process, which takes place under specific conditions, both socio-economic and socio-technical. The socio-economic conditions are: a real mass movement based on voluntary support for collectivisation, a social policy which consolidates the 'welfare cooperative's' role at the outset; pricing and exchange policies which ensure a balance between agriculture and the other sectors, particularly the industrial sector. The necessary socio-technical conditions are: the establishment of an 'undifferentiated' labour process based on mechanisation, a growing division of labour, and a means of control different from the family and landlord forms of labour control discussed above. 
Considering these conditions together makes it easier to understand the constant balancing between economic and technical poles typical of socialist agriculture. Satisfying only one of these conditions at a time (eg mechanisation, use of chemicals) gives little information about the socialist character of this method of control. On the basis of the above remarks and an analysis of policies in the New Economic Zones since 1976, we can see emerging another form of control of surplus labour through the private plot. Let us quickly review the context of the New Economic Zones. As a means of dealing with population pressure and the negative effects of the war (the most complex of which is over-urbanisation), the Vietnamese authorities have decided to reclaim land left fallow in many areas and to clear cultivable land which was inaccessible during the war. This reclamation is being effected by voluntary relocation of the urban population, who receive state aid for the first few months, in the form of housing, food and farming tools. There are two types of unit of production in these areas - cooperatives and state farms. Families who move there are allocated plots which altogether make up five per cent of land area cultivated by the newly formed cooperative. As the members of these cooperatives receive a subsidy from the state, and the labour process is the same as that on the state farms (which mainly employ unmarried young people) the difference between these two types of unit is the existence of the private plot in the former but not the latter. What is note-worthy about this phenomenon is that this land is allocated to the family units by the state. In other words, what we have here is not a survival but a creation.

The aim of the labour process on these private plots is above all to produce goods which the cooperatives' labour process cannot provide under present conditions. Pig-breeding, chicken rearing, vegetablegrowing and kitchen gardens are not efficient areas of production unless industry provides inputs such as chemical fertilizer, electricity, vaccines and small agricultural machinery. The only exceptions are where the products are destined for the family diet where production is achieved by extremely personalised labour. This manual labour is not particularly skilled, and can be done intermittently, by old people, children, or even by the cooperative producers at odd moments during the day.

The plot thus becomes a workplace reserved for members of the family unit and represents a guarantee of the stability of that unit. The plot also allows the productive worker to reduce his or her dead time. To the extent that this worker is also a member of the cooperative, and the means by which labour is controlled becomes progressively more standardised (fixed timetables, division of work into specialised jobs etc) this dead labour time should in theory be progressively reduced by the organisation of cooperative labour. However, this does not happen, and the private plot serves the purpose instead. In concrete terms, the peasant's day is made up of eight hours spent on the cooperative and four or five hours spent on the private plot, with seasonal variations.

Such a long working day would be impossible, were it not for the private plots. And this is the source of the idea of complementarity mentioned above and rejected as a simple empirical description. Our rejection of the zero-sum-game concept of the relationship between work on collective farm and family plot is also made clearer. The only similarity between the two types of work is that they are carried out by the same person, whereas what we really have to consider is two different sorts of control of surplus labour. As long as this control is social, the corollary of the private plot is that its producers be exchanged on the free market, the usual place for the exchange of goods between individual producers. Another corollary is that the stability of the family unit is ensured, this being both the condition for and the effect of the 'private' plot.

As long as the state, or more accurately the cooperatives, are unable to take full control of the land, (and according to Alec Gordon's figures, eight per cent of the land is outside their control, in small plots or inaccessible spots) it would be disastrous not to let individual workers use it. This in fact was one of the most important policies adopted by the Sixth Plenum of the Vietnam Communist Party in September 1979. Similarly, far from prohibiting the free market, the Party has done no more than stress the necessity of controlling it in order to prevent trafficking detrimental to the state. These policies show realism and adaptation to the present situation.

In what way is the private plot a specific form of control of surplus labour in socialist agriculture? On the basis of our remarks above, we are tempted to reply that the plot, at the moment, is a form of redistribution of wealth which takes into account the difference in family size and consequently differing labour capacity. The plot also provides a basis on which the peasants can resist control of surplus labour of the industrial sort, and thus maintain relative stability and control over their equipment. This is not however to skate over the contradictions which the private plot conceals: it maintains the subordination of women, it is the basis on which child labour can be exploited, and it can lead to both clannishness and favouritism. Nor must one present the private plot as the major factor in agricultural development.

It is important to stress that the private plot phenomenon is reproduced in specific conditions 
which must be enumerated. The way the Vietnamese authorities approach family plots is realistic, and conforms with the idea of socialism as conscious and collective control of living conditions and labour.

Finally, will the private plot be abolished under 'developed socialism', with its high degree of mechanisation, or under a more generalised and depersonalised system of control of labour? Will certain forms of the family, the 'market', and even the 'private' labour force disappear with it? Whether the answer is yes or no is not very relevant to present research: the future of these social formations is not given in the present, but will be determined rather by ongoing social struggles, the results of which cannot be predicted.

\section{Rererences}

Campbell, R. W., 1974, The Soviet-Type Economies, Houghton Mifflin, Boston

Dobb, W. M., 1966, Soviet Economic Development since 1917, Routledge Kegan Paul, London
Dunman, J., 1975, Agriculture: Capitalist and Socialist, Lawrence \& Wishart, London

Francisco, R. A. et al (eds), 1979, The Political Economy of Collectivised Agriculture, Pergamon Press, Oxford

Gordon, A., 1978, "Notes on subsistence agriculture and the transition to socialism in Vietnam', Bielefeld University, mimeo

Lazarcik, Gregor, 1974, Agricultural Output and Productivity in Eastern Europe and Some Comparisons with the USSR and the USA, US Congress, Joint Economic Committee, Government Printing Office, Washington DC

Nguyen Xuan Lai, 1967, 'L'economie familiale du paysancooperateur', Etudes Vietnamiennes, no 13

Stavis, B. R., 1979, 'The impact of agricultural collectivisation on productivity in China' in R. A. Francisco et al (eds), op cit

Etudes Vietnamiennes, 1977, 'La Gestion des cooperatives', no 51

Wadekin, K. E., 1973, The Private Sector in Soviet Agriculture, University of California Press, London

Mao Zedong, 1956, 'On the ten great relationships', in his Collected Works, vol V, Foreign Languages Press, Peking (1979) 